\title{
Grønlands udenrigspolitik og internationale relationer: Nuværende rammer og mulig udvikling i et selvstændighedsperspektiv
}

\author{
Mininnguaq Kleist ${ }^{1}$, cand.mag.
}

Rammerne for Grønlands udenrigspolitiske og internationale relationer er emnet for denne artikel. Artiklen kommer ind på de grundlaeggende lovmoessige rammer og strukturer, der goelder og kan komme til at goelde i fremtiden for Grønland. Der ses på Kongeriget Danmarks ${ }^{2}$ enhedsstats-rammer ${ }^{3}$, en mulig forbundsstatsramme og på de mulige rammer under et Free association-forhold ${ }^{4}$ mellem Grønland og Danmark, og hvorledes disse påvirker og kan påvirke Grønlands udenrigspolitiske aktiviteter; herunder iscer den formelle status som Grønland kan opnå på den internationale scene. Artiklen viser, hvorledes Grønlands udenrigspolitiske kompetencer i øjeblikket begraenses, og hvordan de kan udvikles i fremtiden i lyset af ønsket om mere selvstondighed ${ }^{5}$.

Grønlands udenrigspolitiske kompetencer: de nuværende rammer

Grønlands formelle udenrigspolitiske kompetencer er i meget høj grad sat af Grundlovens rammer, navnlig $\S 19$ og $§ 20$, stk. 1, samt kapitel $4^{6}$ om udenrigsanliggender i Lov om Grønlands Selvstyre. Derudover medvirker praksis ${ }^{7}$, der kan være opbygget gennem årene til at sætte rammerne. Selvom Grønland under selvstyreloven ikke kan overtage det udenrigs- og sikkerhedspolitiske område, så kan Naalakkersuisut ${ }^{8}$, "[...] med fremmede stater og internationale organisationer forhandle og indgå folkeretlige aftaler på rigets vegne, herunder forvaltningsaftaler, som alene vedrører Grønland og fuldt ud overtagene sagsområder" (§12, stk. 1). Dog skal betegnelsen for Grønland lyde: "Kongeriget Danmark, for så vidt angår Grønland” (§12, stk. 6).

Hvis man ser på de sagsområder, som Grønland allerede har hjemtaget fra Danmark, er der trods alt en del områder, hvor Naalakkersuisut har formel kompetence til at agere og sætte en politik for sin internationale ageren. Og det vil faktisk være uansvarligt over for det grønlandske folk ikke at gøre dette, da Grønland har kompetencen på hjemtagne områder, også på den internationale scene - ingen andre.

Det skal tilføjes, at Naalakkersuisut skal underrette Danmarks regering om påtænkte forhandlinger, forløbet af forhandlingerne og før, at aftalerne indgås eller opsiges (§12, stk. 5). Denne underretningspligt findes også med omvendt fortegn fra Danmark til Grønland, når folkeretlige aftaler har særlig betydning for Grønland. Da har Danmark pligt til at indhente Naalakkersuisuts udtalelse, og hvis ikke Naalakkersuisut kan tilslutte 
sig den folkeretlige aftale, skal aftalen i videst muligt omfang tilsluttes uden virkning for Grønland (§13, stk. 4).

Til disse rammer kan ligeledes tilføjes den politiske Itilleq-erklæring, der i $2003 \mathrm{blev}$ underskrevet af Landsstyreformand Hans Enoksen og Udenrigsminister Per Stig Møller. ${ }^{9}$ Heri erklæres blandt andet, at:

"I forvaltningen af udenrigs- og sikkerhedspolitiske spørgsmål af betydning for Grønland, er det naturlig, at Grønland medinddrages og har medindflydelse."

"Der er tale om en cegte medinddragelse og medindflydelse med sigte på ligevardighed mellem de to rigsdele i alle spørgsmål, hvor Danmark og Grønland i foellesskab er inddraget."

Danmark har altså juridisk og formelt set de udenrigs- og sikkerhedspolitiske kompetencer i henhold til Grundloven, og senere selvstyreloven. Dog har Danmarks og Grønlands regeringer politisk skrevet under på, at når det kommer til spørgsmål med betydning for Grønland, så er Danmark forpligtet til at give Grønland ægte medinddragelse og medindflydelse med sigte på ligeværdighed. Dette er i overensstemmelse med selvstyrelovens præambel, der understreger Grønlands styrkede position. Den lyder:

"I erkendelse af, at det grønlandske folk er et folk $i$ henhold til folkeretten med ret til selvbestemmelse, bygger loven på et ønske om at fremme ligevardighed og gensidig respekt i partnerskabet mellem Danmark og Grønland. Loven bygger i overensstemmelse hermed på en overenskomst mellem Naalakkersuisut og den danske regering som ligevardige parter. "10

Læg mærke til formuleringen - det grønlandske folk er et folk $i$ henhold til folkeretten med ret til selvbestemmelse, for ikke at nævne begreberne ligevardighed og gensidig respekt. Der er således et ønske om større ligeværdighed mellem de to regeringer. Hvis en sag for eksempel omhandler forhold gældende inden for Grønlands geografiske område eller inden for Grønlands regionale nærområde, og/eller hvis sagen vil være af den grønlandske befolknings interesse eller måske endda påvirke det grønlandske folks levevilkår, samfund, miljø eller lignende, da vil det være passende og korrekt at inddrage det grønlandske folks repræsentanter i beslutningsprocessen. Mange af de overtagne sagsområder influerer i sagens natur direkte på det grønlandske folks levevilkår og miljø. Det kan yderligere bemærkes, at danske beslutningstagere ikke er demokratisk valgte i Grønland, og har i meget sjældne tilfælde boet i Grønland. Det ville være udemokratisk ikke at involvere Grønland i sager, hvor det grønlandske folk berøres. Itilleq-erklæringen og senere selvstyreloven retter formelt set politisk op på dette, da det er sværere at forsøge at ændre på Grundlovens bogstav samtidig med, at der er rum for fortolkningen af Grundloven, 
hvilket understreger pointen om, at praksis også er definerende for rammerne af Grønlands udenrigspolitiske kompetence.

Lovgivningen sætter rammerne for Grønlands internationale aktiviteter, men definerer ikke Grønlands internationale relationer, der i stedet styres af Grønlands interesser og de internationale fora, som Grønland bevæger sig inden for - og som ikke nødvendigvis udelukkende er defineret af de sagsområder, som Grønland har overtaget. Det kan for eksempel være regionale fora såsom Arktisk Råd, som Grønland ikke selv er medlem af i eget navn, men hvor Grønland ikke desto mindre er meget aktiv. Derudover kan Grønlands internationale relationer også blive påvirket af dynamikker og udviklinger på den internationale politiske scene, hvor det er andre lande og magters handlinger og interesser i regionen eller på verdensplan, der (delvist) sætter dagsordenen. Eksempelvis kan Ruslands øgede militære kapacitet $\mathrm{i}$ regionen medvirke til at påvirke den politiske debat $\mathrm{i}$ Arktis, ligesom en ny regering i USA kan have prioriteter, som igen kan påvirke dagsordenen i Arktisk Råd. Grønland har naturligvis kompetencen til at have en holdning og arbejde for målsætninger i sager og emner, som berører Grønland og Arktis. Det er ikke nødvendigvis ensbetydende med, at Grønland også kan opnå, hvad Grønland ønsker sig i en sag (ligesom Danmark udenrigspolitisk heller ingen garantier har for at kunne opnå hvad Danmark ønsker). Men det betyder, at Grønland i det mindste kan arbejde for sine målsætninger og forsøge at påvirke relevante aktører i retning af Grønlands interesser. Og under alle omstændigheder, har Naalakkersuisut en forpligtelse til at varetage sit folks interesser - som det grønlandske folks demokratisk valgte regering.

\section{Grønlands udenrigstjeneste og internationale aktiviteter}

Grønland har siden 1994 haft et udenrigskontor under det daværende hjemmestyre på trods af, at Danmark havde og har de grundlæggende udenrigspolitiske kompetencer i henhold til Grundloven. Den stigende udenrigspolitiske interesse fra grønlandsk side medførte, at kontoret blev opgraderet til "Udenrigsdirektoratet" i 2004, og derved signaleredes en politisk opgradering af udenrigsanliggenderne i Grønland. I 2018 blev Udenrigsdirektoratet, efter at have været et departement sammen med selvstændigheds- og landbrugsafdelingerne, sit eget separate selvstændige departement: Departement for Udenrigsanliggender. På det administrative og operationelle plan har der på den måde været en gradvis udvikling, som er kommet af et stadig større politisk ønske om at opgradere udenrigstjenestens status. Det er ligeledes blevet stadig mere klart, at en egen udenrigspolitisk og international indsats er nødvendig i varetagelsen af Grønlands sagsområder og interesser. På fiskeri-, skatte-, forsknings-, klima-, ocean-, miljø-, kommunikations-, infrastrukturområdet, osv. er det således nødvendigt at være opmærksom på internationale udviklinger og krav. Og som det indikeres af ovenstående, er det ikke kun Departementet for Udenrigsanliggender, der må højne sit internationale aktivitetsniveau, men også andre fagdepartementer i Grønlands Selvstyre der i høj grad også er nødt til at 
påtage sig opgaver på den internationale scene, hvilket må siges at være en direkte konsekvens af globaliseringen. Grønland ønsker selv at udvikle sine sagsområder, og gerne i samarbejde med eksterne partnere. Men det er også klart, at der kommer stadig flere krav fra omverden til alle parter som ønsker at være eller allerede er del af internationalt samarbejde. Krav der går på transparens, bæredygtighed, udveksling af informationer, sikkerhedskrav, deltagelse i internationale møder, etc. Det er områder og forhold, som Danmarks Udenrigsministerium eller andre danske fagministerier ikke vil kunne håndtere på $100 \%$ effektiv vis, for så vidt angår Grønland, da internationale forhandlinger kommer ind på alle mulige og uforudsete aspekter omkring det emne, der nu en gang forhandles om. Det kræver et endda meget detaljeret kendskab til emnet og det samfund man forhandler på vegne af. Noget danske ministerier er fuldt ud kvalificeret til at gøre for så vidt angår Danmark og det danske folk, men slet ikke på samme niveau for så vidt angår Grønland og det grønlandske folk, uden involvering af grønlandske repræsentanter. De to lande, folk, kulturer, levevilkår, udviklingsniveau og samfundsmæssige behov er ikke ens, og det afspejler sig i interesserne og hvad repræsentanterne skal være opmærksomme på. At grønlandske repræsentanter bedre kender Grønland og dets folk, leder lige så naturligt til, at Grønland ønsker at lade sig repræsentere af sine egne folk, der med bedre repræsentativitet, mere troværdighed og viden kan repræsentere Grønland direkte og mere effektivt. I internationale fora, f.eks. Arktisk Råd, vil Grønland skulle dele sin korte taletid med Danmark (og Færøerne). Derved vil grønlandske budskaber forkortes og skulle tilpasses Danmark og Færøerne, som i bund og grund ikke er arktiske, og hvis befolkninger ikke berøres nævneværdigt af beslutninger i Arktisk Råd. Der hvor danske repræsentanter derimod kan bidrage positivt, er med ekspertise, diplomatiske erfaring, kontakter og viden om mekanismer i de store multinationale organisationer (f.eks. FN og EU) og bilaterale aktiviteter, samt med de flere ressourcer, som det danske embedsapparat besidder. Noget Grønland efter egne forhold snarere kan siges at være i opbygningen af. ${ }^{11}$

\section{Grønlands repræsentationer i udlandet}

Grønland har repræsentationer i Bruxelles over for EU, i Washington DC over for USA og Canada, samt i Reykjavik over for Island. Derudover varetager Repræsentationen i Danmark også opgaver over for det diplomatiske korps i Danmark. ${ }^{12}$ Grønlands repræsentationer i udlandet kan oprettes i henhold til selvstyrelovens $§ 15$ :

"Efter ønske fra Naalakkersuisut ansœettes der ved Kongeriget Danmarks udenrigsreprcesentationer reprosentanter for Naalakkersuisut til varetagelse af grønlandske interesser inden for sagsområder, som fuldt ud er overtaget af selvstyret. Regeringen kan bestemme, at udgifterne herved skal afholdes af Naalakkersuisut." 
Grønlands diplomatiske udsendinge finansieres gennem Grønlands finanslov og udsendes gennem Udenrigsministeriets system, og placeres i et for så vidt muligt selvstændigt afsnit af den danske repræsentation i det pågældende land. I Reykjavik er den grønlandske repræsentation placeret $i$ en anden del af byen, da der ikke er plads i den danske ambassade.

Den løbende kontakt, hvor grønlandske diplomater fra Nuuk fra tid til anden mødes med andre landes udsendinge udenfor repræsentationernes virke, er også et vigtigt redskab. Denne kontakt er uundværlig og har sine egne formål. En permanent repræsentation kan i de pågældende lande, over en længere periode mere direkte bygge diplomatiske forhold op tæt på policy-makers og beslutningstagerne i de pågældende lande. Hvis der ikke er oprettet en grønlandsk repræsentation i det pågældende land, foregår den løbende kontakt i høj grad gennem danske udsendinge, som er fagligt dygtige, men vel at mærke er folk, der i nogle tilfælde aldrig har været i Grønland og ikke på tæt hold kender til generelle grønlandske forhold, eller kender til de interne grønlandske politiske dynamikker, holdninger og diskussioner inden for relevante emner. Det er en svaghed. Derudover kan der inden for nogle spørgsmål være forskellige hensyn, interesser og synsvinkler omkring sagerne, alt efter om man repræsenterer Danmark eller Grønland. Derfor er det absolut at foretrække at have grønlandske udsendinge til at repræsentere Grønland i udlandet.

Generelt om flere grønlandske repræsentationer

Under selvstyrelovens $§ 15$ er det som tidligere nævnt muligt for Grønland at åbne flere repræsentationer i andre lande. Kina, Japan, Storbritannien (efter Brexit) og Canada har gennem årene været nævnt. Alle disse lande giver mening set ud fra Grønlands udvikling, geopolitiske position, Arktis, fiskeripolitik, miljøpolitik, klimapolitik, forskning, handelsinteresser, osv. I fremtiden vil det også være relevant at overveje en repræsentation i New York over for FN, måske endda i en tid, hvor Grønland stadig har selvstyre inden for Kongeriget Danmark. Det er ikke nødvendigvis ensbetydende med, at Grønland skal være medlem af FN lige med et, da det kun er suveræne stater, som kan være medlemmer. En nuværende akkreditering vil foregå under det danske udenrigsministerium, som i de andre udsendtes tilfælde. Der foregår et stort antal møder og events med interesse for Grønland i FN-systemet, og mange internationale politiske udviklinger og indsatser sættes i gang her. Under FN er der således vigtige møder og konferencer omhandlende emner, som klima, menneskerettigheder, biodiversitet, den brede oceanmiljø-agenda, bæredygtighedsmålene, osv. Emner, der alle er politisk opmærksomhed omkring i Grønland. Udover at FN's Generalforsamling er interessant for Grønlands politiske system, så har de oprindelige folks Permanente Forum sine årlige møder i New York. Desuden findes FN's afkoloniserings-sekretariat i New York, hvilket kan være relevant i det tilfælde, Grønland overvejer Free Association-modellen (se nedenfor) eller fuld selvstændighed, 
da Grønland indtil 1954 fremgik af FN's liste over ikke-selvstyrende territorier (kolonierne).

Der skal således ikke herske nogen tvivl om, at Grønland kan åbne flere repræsentationer på samme niveau under de nuværende rammer, hvor Grønland har selvstyre og er en del af Kongeriget Danmark. Spørgsmålet om oprettelse af ovennævnte repræsentationer er politiske spørgsmål - og et ressourcespørgsmål. Det er er ikke gratis at oprette disse repræsentationer, ligesom der skal være personale dertil, som kan repræsentere Grønland på passende vis.

Min egen personlige opfattelse er, at disse stillinger, ikke blot kan besættes af ikke-grønlandske folk, som man blot hiver ind til at repræsentere Grønland og det grønlandske folk. Tiden er ikke til dette mere. Man må i det mindste have boet i Grønland i et større antal år, kende landet, kende folket og have et vist kendskab til sproget og kulturen. Man skal helst også have et vis internt kendskab til Grønlands Selvstyre, de politiske dynamikker i landet, departementerne, arbejdsmetoderne i selvstyret og have kontakterne ind i systemet, da disse er essentielle for arbejdet, der skal udføres under udstationeringen. Det er heller ikke helt uvæsentligt, at vedkommende også har et vist kendskab til internationalt samarbejde, diplomati og udenrigspolitik bredt forstået. Det er meget svært - for ikke at sige umuligt - at repræsentere det land og folk du er udsendt fra på passende og effektiv vis, hvis du ikke har disse forudsætninger og viden på plads. Det lægger en naturlig begrænsning på hvem, der kan udstationeres, da kandidatfeltet snævres ind. Det betyder også, at det tager tid at opbygge en udenrigstjeneste og besætte stillingerne i de forskellige repræsentationer med kvalificerede folk.

\section{Sikkerhedspolitik}

Opfattelserne af sikkerhedspolitik er adskillige og forskellige, herunder hvad det omfatter og implicerer. Ifølge nogle opfattelser, omhandler sikkerhedspolitik groft sagt udelukkende kanoner, raketter og militære bevægelser, der kan true den nationale sikkerhed. Andre udvidede opfattelser af sikkerhedspolitik, inddrager større investeringer, adgang til kritiske naturressourcer, infrastruktur og forsyningslinjer, kommunikationslinjer, kortlægning, forskning og detaljeret viden om regionen og andre felter, som havende potentielle forskellige sikkerhedspolitiske implikationer ${ }^{13}$. Et eksempel er de meteorologisk observationers vigtighed i Østgrønland under 2. Verdenskrig; vejrets udvikling var essentiel viden forud for diverse militære bevægelser. En negativ udvikling på nogle af de nævnte områder kan medføre en forringet mulighed for at forsvare den nationale sikkerhed. Hvis den "rette" kombination af geografi, karakteren, omfanget og aktørerne i et givent industrielt eller infrastrukturelt projekt, involverede relationer og muligvis andre faktorer er til stede, kan det pågældende projekt medføre sikkerhedspolitiske implikationer, som man er nødt til at tage højde for og vurdere ifølge et udvidet syn på sikkerhedspolitik. Eksempelvis, hvis et større tredjeland tilbød at kortlægge Grønland, så ville Grønland kunne få nye opdaterede detaljerede hav- og landkort, i stedet for de gamle upræcise 
kort, som Grønland i dag har fra 1930'erne. Dette kan givetvis afvises med henvisning til sikkerhedspolitiske forhold (og hvis andre relevante forhold i øvrigt peger i den retning), idet præcise kort kan give geografisk viden, som er af fundamental vigtighed $i$ en militærsammenhæng.

Grønland har ikke et forsvarsmæssigt kompetenceansvar, men Grønland har kompetencen inden for en række sagsområder, der kan have konsekvenser for evnen til at forsvare sig eller forrykke balancerne i regionen. Grønland kan i henhold til selvstyreloven ikke overtage sikkerheds- og forsvarspolitikken, ligesom udenrigspolitikken $i$ henhold til den danske regerings tolkning af Grundloven formelt set ikke kan overtages med kompetence som en selvstændig suveræn stat. Det betyder således ikke, at Grønland ikke må følge med inden for disse områder (bredt forstået), vurdere og danne sig en eventuel holdning, definere sine interesser og agere derefter - som en ikke-selvstændig stat (det skal erindres, at Grønland faktisk har kompetencer tæt på en selvstændig stat inden for overtagne sagsområder). Når Grønland befinder sig i en geopolitisk vigtig region med øgede aktiviteter inden for forskellige sektorer, er Grønland nødt til at have kvalificeret viden og ekspertise omkring hvorledes, der skal ageres i regionen, således at man beskytter og varetager sine interesser bedst muligt. Det er helt legitimt - og det er faktisk Naalakkersuisuts ansvar. Samtidig skal Grønland også have ekspertisen til at vide, hvornår Grønland risikerer at forrykke eventuelle balancer i regionen. Med stadig mere aktivitet i regionen, vil der komme stadig flere komplekse forhold og scenarier at tage stilling til. Dette uanset, om Grønland befinder sig i en selvstyrestatus, i et Free Association-forhold med Danmark, eller fuldt ud selvstændig som suveræn stat. Blandt andet derfor har Grønland et Departement for Udenrigsanliggender, og derfor er der god ræson i, at Grønland begynder at styrke sin sikkerhedspolitiske analytiske kapacitet, der kan rådgive ud fra et grønlandsk perspektiv, og hvor egne borgeres livsvilkår i sådanne vurderinger også skal veje tungt. For situationen i Arktis - Grønlands geopolitiske situation - må ikke komme til at betyde, at Grønland forhindres $i$ at foretage sig noget, der ændrer en smule på gældende forhold. Vurderinger formes efter, hvorledes den der vurderer, ser tingene, og hvor vedkommende kommer fra. Det er således nødvendigt med informerede beslutningsgrundlag og beslutninger, som medtager det grønlandske perspektiv, der ikke nødvendigvis er det samme som perspektivet fra Danmark.

Grønland har ikke selv et eget militær. Det har Island for eksempel heller ikke, men alligevel er Island medlem af NATO. For Grønlands vedkommende og i et eventuelt Free Association-forhold (se afsnit om Free Association længere nede i artiklen) til Danmark, eller i en selvstændighedssituation, vil en tilpasset ordning af varetagelsen af den militære suverænitet skulle indgås med andre NATO-medlemslande, hvis ikke Danmark fortsat vil varetage suverænitetsopgaver i Grønland. I det scenarium er det sandsynligt, at USA fortsat vil ønske at opretholde sin tilstedeværelse i Grønland, og USA vil dermed enten alene eller i samarbejde med andre NATO-lande varetage suverænitetshåndhævelsen. Helt usandsynligt er det dog ikke, at Danmark vil være behjælpelig med at håndhæve suverænitet i Grønland, hvis Grønland ønsker dette. Hvis Danmark opgiver sin tilstedeværelse i Grønland og lader det være op til USA (såfremt USA ønsker dette) at udfylde 
tomrummet fra Danmark alene, vil denne udvikling muligvis være med til at forrykke balancen på det militære plan i Arktis, da særligt Rusland måske vil se det som et styrket USA i regionen. Og USA er noget andet, end Danmark.

Måske er det således ikke helt usandsynligt, at der kan komme et vist pres på Danmark fra nabolande og i NATO om, at det er mest formålstjenstligt, at Danmark fortsætter med at hjælpe et selvstændigt Grønland med suverænitetshåndhævelsen for ikke at forrykke sikkerhedsbalancen for meget i regionen.

Lad os nu se på, hvordan Grønlands udenrigspolitiske kompetence vil se ud, hvis den nuværende statslige konstruktion bliver ændret fra en formel enhedsstat til en forbundsstat, eller hvis det nuværende selvstyre erstattes af Free Association.

Mulig fremtidig udvikling i et selvstændighedsperspektiv

\section{Forbundsstats-modellen}

Hvordan løser vi udfordringerne med Grundlovens rammer og den stramme tolkning deraf, og fastsætter nogle kompetencer og rammer, som tilfredsstiller en grønlandsk ambition henimod en større udenrigspolitisk kompetence og mere selvstændige medlemskaber af mellemfolkelige organisationer og lignende? Inden for selvstyrelovens rammer kan det med den nuværende tolkning af Grundloven blive endda meget svært at opnå dette, da Grønland stadig ikke er en selvstændig stat. Hvad Grønland derimod kan opnå mere af inden for nugældende rammer, er mere af det samme, som Grønland principielt kan i dag. Det vil sige, at Grønland kan oprette flere udenlandske repræsentationer på samme niveau (som selvstyrende land) - fortrinsvist i forbindelse med de danske ambassader (med mindre praktiske forhold taler for andet), som det foreskrives $§ 15$ i selvstyreloven. Grønland kan opnå mere synlighed, mere ekspertise og måske endda større/flere resultater - f.eks. inden for det arktiske samarbejde, FN-arbejdet og/eller i samarbejdet med EU, hvis den grønlandske udenrigstjeneste styrkes med flere ressourcer. Det er vel at mærke inden for de samme områder/niveauer, som Grønland agerer inden for i dag.

Som udgangspunkt kan Grønland under nugældende rammer ikke forvente at blive medlem af mellemfolkelige organisationer, hvor kun suveræne stater er medlemmer. Det modsatte vil kræve, at Grønland enten blev at betragte som en suveræn stat i det pågældende forum, som følge af, at Grønland de facto har kompetencer som en suveræn stat, og at dette anerkendes i den pågældende organisation. Ofte er det dog ikke nok at have kompetence som en suveræn stat på et relevant område, for at blive betragtet som en suveræn stat - man skal i nogle tilfælde være anerkendt som en suveræn stat i FNsammenhæng. Det kommer an på den pågældende organisation og flertallet af organisationens medlemmers holdning til spørgsmålet. Det vil sige, at det i nogle tilfælde vil være et politisk spørgsmål. Men hvor dette spørgsmål besvares positivt, har den danske stat nu åbnet op for, at Grønland kan blive medlem i eget navn. 
En mulig ide for at løse op for denne problematik har været forbundsstatsmodellen. En forbundsstat udgøres af flere delstater eller provinser, som hver især har delstatsforfatninger med lokale kompetencer. Delstaterne er gået sammen i et forbund eller føderation. Under denne ide, vil Grønland have del-statslige status, hvilket muligvis gør, at forbundsstats-ideen nævnes fra tid til anden - men altså vel at mærke stadig ikke med status som suveræn stat.

I et sådan statsligt forbund findes en lokal statslig regering, og over det en øvre central forbundsstatsregering, med en overordnet central myndighed, med kompetence til at repræsentere og definere den samlede stat udadtil. Kompetencen på forsvars- og sikkerhedspolitikken vil typisk være placeret centralt i forbundsstaten. For så vidt angår Højesteret, valutaen og statsborgerskab vil kompetencen typisk også være placeret i forbundsstatens hovedstad. Forbundsstaten vil hvile på en central forfatning, der blandt andet sætter rammerne for delstaternes ageren. Myndigheden og kompetencen over forbundsstatens forfatning vil være placeret i forbundsstatens hovedstad. Kort og groft ridset op. Det som ideen om forbundsstaten som løsning overser er, at forbundsstater repræsenteres udadtil i mellemfolkelige sammenhænge af forbundsstatens regering. Forbundsstatens regering har for eksempel kompetencen for medlemskab af mellemfolkelige organisationer - f.eks. FN, EU, NATO, NEAFC ${ }^{14}$, Arktisk Råd, (IOC) ${ }^{15}$, etc. Her er det for eksempel ikke Californien, Bayern eller British Colombia, som er medlem, men derimod de føderale-, konføderale- og forbundsstatsregeringer for USA, Tyskland og Canada, der varetager medlemskaberne. Delstaterne kan i nogle tilfælde i det uformelle og "lavere-rangerende" fora og arbejdsgrupper arbejde for eller lobby for deres interesser - hvilket Grønland i øvrigt også kan i dag.

Ifølge min opfattelse er forbundsstats-modellen derfor ikke attraktiv for Grønland, da den ikke vil løse problematikkerne med en "central Grundlov", eller for Grønlands muligheder for medlemskaber i eget navn i mellemfolkelige organisationer og internationale fora. Grundlæggende vil rammerne for Grønlands udenrigspolitiske virke ikke være meget anderledes end i dag, da der ikke er forskellige regler for enhedsstater og forbundsstater på den internationale scene.

Forbundsstats-konstruktionen vil heller ikke gøre det muligt for Grønland at indgå selvstændige folkeretlige aftaler med tredjelande i eget navn, og uden at Danmark skal godkende disse og eventuelt være medunderskriver - og i øvrigt muligvis deltage i forhandlingerne forud for disse. Grønland vil ikke kunne oprette egne selvstændige ambassader eller udpege egne grønlandske diplomatiske ambassadører, da det kun er suveræne stater ${ }^{16}$, der kan udpege ambassadører i diplomatisk sammenhæng.

Hvis Grønland valgte forbundsstatsmodellen, kan det blot siges at være en fortsættelse af "integrations-modellen", som er en af de tre valgmulighederne under FN's afkoloniseringsproces (se afsnit nedenfor). 


\section{Free Association}

Free Association er en ordning, der blev anerkendt i FN under verdenssamfundets afkoloniserings-indsats i det 20. århundrede. Efter afslutningen på to verdenskrige var det tid til, at verdens nationalstater gjorde en indsats inden for områder, som skabte ufred og diskrimination mellem lande og folk. Således blev diskrimination mellem mennesker, social ulighed, økonomisk udvikling, og generel styrkelse af samarbejde mellem nationer prioriteter under FN. Det var her, at afkoloniseringen blandt andre indsatsområder kom til, da koloniforhold grundlæggende er udtryk for ulighed mellem mennesker, udnyttelse og mangel på respekt. De tidligere kolonier - de "ikke-selvstyrende territorier"17 - fik endda deres eget kapitel i FN-pagten: Kapitel XI. ${ }^{18}$

Fra slutningen af 1940'erne og op igennem 1950'erne forhandlede FN's medlemsstater forskellige grundlæggende politiske udviklingsmuligheder for kolonierne på plads. ${ }^{19}$ Disse muligheder blev endeligt vedtaget i 1960. FN's Generalforsamlings Deklaration $1514^{20}$ - hvor FN's medlemsstater erklærede og grundlæggende fastlagde de koloniserede folks fundamentale ret til selvbestemmelse og selvstændighed - blev vedtaget. FN's Generalforsamlings Resolution $1541^{21}$ - der eksplicit nævnte de tre politiske udviklingsmuligheder for de ikke-selvstyrende territorier - blev også vedtaget i 1960.

De tre muligheder var:

1) Integration $i$ kolonimagten

2) Free Association ${ }^{22}$

3) Fuld selvstændighed

Opfattelsen var under FN's afkoloniseringsarbejde (vedtaget af medlemsstaterne), at disse tre valgmuligheder ville give kolonierne mulighed for politisk udvikling, som passede bedst til den enkelte koloni. Koloniernes befolkninger skulle vel at mærke selv vælge på informeret vis, hvilken mulighed de ønskede for deres folk og land i dets politiske udvikling. For at de kunne vælge dette, skulle det grundlæggende først anerkendes, at kolonierne havde en fundamental ret til selvstændighed. Således udtalte den danske delegationsleder, tidligere minister Ernst Christiansen, under indlæggene i FN's generalforsamling ved behandlingen af resolution 1514, at: "Det er således fuldt forståeligt, at vi fra dansk side uforbeholdent kan vore med til, at FN nu i en deklaration understreger, at tiden er inde til den endelige ophoevelse af alt kolonistyre."

I forbindelse med deklarationens stk. 3 udtales bland andet:

" Det må endelig også erindres, at der vel altid hos dem, der er herskende over et område, over en nation eller blot over en gruppe af mennesker, vil vore en tilbøjelighed til at mene, at de beherskede ikke er modne nok. [...] Men lad mig som konklusion sige, at det nok vil vare rigtigst at regne med, 
at de folk, som vil vore fri, har travlt, og at man ikke ved påskud, der er mere eller mindre konstruerede skal kunne hindre dem i at nå frihed. Jeg vil noermest formulere det sådan: hellere frihed og selvstcendighed for tidligt end for sent." 23

Danmark stemte for.

Grønland blev en formel del af det danske rige i 1953, gennem nugældende Grundlov. De ovennævnte tre valgmuligheder blev ikke præsenteret for Grønland, ej heller det grønlandske landsråd, selvom de tre muligheder på dette tidspunkt allerede var kendt gennem arbejdet med Faktorlisterne under FN's 4. udvalg. En del af grunden til det var, at Grønland var et lukket land i denne periode, hvorfor det var meget begrænset hvilke oplysninger, der fandt vej ind i det grønlandske samfund. Grønlands landsråd (der i øvrigt ikke havde mandat til at træffe en sådan beslutning) ${ }^{24}$ fik tre dage i september 1952, hvor muligheden 'ja eller nej til integration ind i Danmark' blev fremlagt af Danmark. Hvis ikke landsrådet valgte integrationen, ville Danmark efterlade Grønland til at sejle sin egen usikre sø. Den sidste mulighed - på den måde, som den blev fremført - ville nok ikke have været acceptabel for verdenssamfundet og det ansvar, som kolonimagterne fik pålagt sig under FN's afkoloniseringsproces. Der blev ikke orienteret om FN-afkoloniseringsudviklingen over for landsrådet. De valgmuligheder som landsrådet fik, var således ikke i tråd med de retningslinjer og muligheder, som der internationalt blev arbejdet efter i FN, og som senere endeligt blev vedtaget under FN's afkoloniseringsproces i 1960. Det var således ikke en informeret demokratisk beslutning i 1952, idet landsrådet blev fraholdt grundlæggende information. Grønland var indtil 1954 at finde på FN's liste over ikkeselvstyrende territorier ${ }^{25}$. Efter indlemmelsen i Kongeriget Danmark gennem Grundloven af 1953, blev Grønland taget af listen i 1954.

Den mangelfulde "demokratiske" proces i 1952 var medvirkende årsag til, at Den Grønlandsk-danske Selvstyrekommission kom frem til, at det grønlandske folk stadig har ret til at vælge Free Association (og for den sags skyld også de to andre valgmuligheder ovenfor), hvilket afspejles i lovbemærkningerne ${ }^{26}$ til selvstyreloven, hvor Free Association nævnes som en fremtidig mulig samarbejdsordning. Dette som en form for mellemstadium $i$ en selvstændighedsproces - og som alternativ til de to andre nævnte muligheder ovenfor - integration (som det blev i 1953), og fuld selvstændighed.

\section{Fra Selvstyre til Free Association}

Free Association-ordningen er altså en ordning, hvor to stater samarbejder, men hvor hver stat er at betragte som sin egen stat med hver sin forfatning. Ingen er juridisk underlagt den anden. Den ene stat - typisk den tidligere kolonisator - har en større kapacitet (f.eks. administrativt, forsvarsmæssigt, mere udviklet sundhedsapparat og flere uddannelsesinstitutioner, osv.) og assisterer den anden stat - den tidligere koloni - der stadig har en 
begrænset kapacitet til at håndtere alle ansvarsområderne under sig. Der er ingen fastlagte rammer for, hvorledes de økonomiske rammer skal være mellem parterne. Det fastlægger parterne indbyrdes. Men det vil grundlæggende sige, at en model med bloktilskud, oprettelse af en økonomisk fond, nedtrapning af tilskud, eller slet ingenting i princippet er muligt. Der vil til gengæld også være større selvstændighed for det frit associerede territorium/ø til at forfølge egne økonomiske interesser på egen hånd. De konkrete samarbejdsområder mellem de to stater fastlægges ved en traktat, og denne "aftale" kendetegner Free Association-forholdet. Traktaten kan fornyes og opdateres hen ad vejen, f.eks. efter et bestemt års-interval, og parterne kan senere også beslutte at ophæve traktaten.

Free Association-ordningen er interessant, fordi den vil kunne løse op for problematiske forhold, som er at finde under nugældende enhedsstats-konstruktion, og som forbundsstats-konstruktion heller ikke kan være svar på. Baggrunden for dette er, at Grønland kort sagt hives ud af Grundlovens begrænsende rammer, og i stedet træder Grønlands egen forfatning i kraft. Der kommer heller ikke til at være en ydre forbundsstats-forfatning udover den grønlandske forfatning. Den grønlandske stat bliver således ikke del af et større forbund af stater. Den grønlandske stat bliver staten udadtil. Særligt inden for forsvars- og sikkerhedspolitikken, kan der være et tæt samarbejde, men ikke nødvendigvis en underlæggelse af den frit associerede over for den anden stat, men snarere assistance eller samarbejde. I Free Association-forholdet vil Grønland således ikke være omfattet af en anden ekstern og begrænsende statslig konstruktion (enhedsstat/forbundsstat) med et ansigt udadtil, hvilket - i sin nuværende form - er begrænsende for Grønlands ønsker om at varetage egne interesser fuldt ud og repræsentere sig selv. Grønland vil endda kunne søge medlemskab af FN i eget navn, hvilket andre Free Association-stater så som Marshall Islands, Mikronesien og Palau allerede er. ${ }^{27}$ Stater med sammenlignelige små befolkningsgrundlag.

Mikronesiens, Marshall Islands og Palau's Free Association-ordninger med USA kaldes "Compact of Free Association"28. Blandt de områder, som dækkes af COFA'erne, er udenrigsanliggender, immigration, borgerrettigheder, miljøbeskyttelse, uddannelsesområdet, sundhedsområdet, økonomiske relationer, valuta, handel, sikkerheds- og forsvarsrelationer, osv.

Cook Islands Free Association-ordning med New Zealand trådte i kraft i $1965^{29}$, samtidig med, at Cook Islands egen forfatning trådte i kraft. I 2001 blev Free Associationordningen mellem de to lande fornyet ved en Joint Centenary Declaration ${ }^{30}$ og underskrevet af de to landes regeringschefer. I denne berøres områder som udenrigsanliggender, sikkerheds- og forsvarspolitik, osv. Cook Islands har valgt ikke at blive fuldgyldigt medlem af FN, og Cook Islands folk er statsborgere i New Zealand, selvom New Zealand har anerkendt, at Cook Islands kan agere som en stat.

Det siger sig selv, at Free Association-ordningen er en ordning, som er anerkendt under FN. Den dybe tallerken skal ikke opfindes på ny, hvis det er den ordning, der sigtes efter for Grønland. Der er erfaringer, der kan trækkes på fra andre steder i verden, hvor Free Association-ordningen er og har været benyttet. Ordningen er ikke perfekt. Der vil være forhold som passer til en bestemt relation, men som ikke er egnet til et andet Free 
Association-forhold. Således er det ikke nødvendigvis alle elementer i Free Associationforholdene mellem USA over for Palau, Marshall Islands og Mikronesien, der er egnet til et eventuelt Free Association-forhold mellem Danmark og Grønland. USA's store militær-operationelle interesser i Stillehavs-regionen afspejles i Free Association-aftalerne. Her er forholdene i Arktis anderledes, og Danmark er ikke en militær supermagt, som USA er det.

Det samme gælder for forholdet mellem New Zealand og Cook Islands. Cook Islands har valgt ikke at blive medlem af FN som stat, men er medlem af underorganisationer af FN; bl.a. UNFCCC. ${ }^{31}$ Cook Islands er medlem af IOC, da Cook Islands nåede at blive medlem før, at stramningerne for IOC-medlemskab blev vedtaget i den sidste halvdel af 1990'erne. Hvis Grønland under et Free Association-forhold med Danmark ønsker at opnå et selvstændigt medlemskab af FN, vil det ikke kunne hænge sammen med, at grønlændere i Grønland stadig har et dansk statsborgerskab på samme måde, som Cook Islændere har beholdt deres newzealandske statsborgerskab. Et eget grønlandsk statsborgerskab må være etableret og en forudsætning for, at man kan anerkendes som en selvstændig stat i en FN-sammenhæng.

Det grundlæggende interessante i disse Free Association-forhold er den juridiske struktur, der skaber Free Association-forholdene mellem de nævnte lande. Strukturen er særlig interessant, da der er tale om to stater med egne forfatninger side om side, og ingen ydre ramme, der formelt dikterer "ansigtet udadtil" - den internationale profil. Derimod er der traktater mellem de to stater, der sætter rammerne for samarbejdet.

I det tilfælde, at Grønland er kommet i et Free Association-forhold med, sandsynligvis, Danmark og Grønland har søgt og opnået et FN-medlemskab - og derved blevet bredt anerkendt som selvstændig stat - da vil Grønland i tilgift kunne blive medlem af forskellige internationale organisationer og fora i eget navn. Disse inkluderer Arktisk Råd, IWC ${ }^{32}$, UNFCCC, IOC og helt sikkert de forskellige fiskeriorganisationer, som Grønland i dag er aktiv i, men hvor man må "dele" medlemskabet med Færøerne under betegnelsen 'Kongeriget Danmark'. Derved vil Grønland også have muligheden for at kunne forfølge og forsvare sine interesser direkte og mere potent. Grønland vil kunne oprette ambassader og konsulater, samt udpege egne diplomatiske ambassadører. Det vil kræve en styrkelse og udvidelse af den grønlandske udenrigstjeneste, hvilket også er muligt, hvis ressourcerne allokeres dertil. De eksisterende Free Association-tilfælde med små befolkninger ude i verden viser, at dette er muligt. Antallet af disse repræsentationer behøver ikke at være højt, og bemandingen af repræsentationerne behøver heller ikke at være omfattende, idet aktiviteterne naturligt må tilpasses egen kapacitet ${ }^{33}$. Øerne samarbejder desuden i FN-regi og i andre sammenhænge under Alliance of Small Island States (AOSIS) samt Small Island Developing States (SIDS), hvilket til dels afhjælper den ofte manglende kapacitet hos den enkelte østat, idet østaterne sammen kan dække flere interesseområder på én gang.

De emner der adresseres i Free Association-ordningerne, er således absolut interessante og relevante i en grønlandsk politisk udviklingssammenhæng, og med tanke på 
de udfordringer, der også findes i dag. Det er der selvfølgelig en grund til, idet Free Association er udtænkt til tidligere kolonier, og Grønland er en tidligere koloni.

Derfor ser jeg Free association-ordningen, som en meget spændende ordning som allerede anerkendes som en mulighed under selvstyreloven - der vil kunne løse mange af de udfordringer, der findes internt i Kongeriget Danmark. Det vil samtidig være en ordning, der langt hen ad vejen, vil kunne tilfredsstille de grønlandske ønsker, der ellers kun kan imødekommes ved fuld selvstændighed som stat.

\section{Konklusion}

Med selvstyre og under selvstyreloven, vil Grønland grundlæggende kunne udvikle og opnå mere af det samme på samme niveau, men mere ekstensivt, under det udenrigspolitiske område og i sine internationale relationer. Den nuværende udvikling kan fortsætte under selvstyret. Flere bilaterale repræsentationer på hidtidigt niveau kan oprettes, hvis ressourcerne og kapaciteten hæves. Grønland vil i det tilfælde - i højere grad end i dag også kunne præge dagsordenen inden for områder, hvor Grønland har interesser. Her tænkes ikke nødvendigvis kun på kapacitet og ressourcer tilført Departementet for Udenrigsanliggender, men også til andre relevante departementer, der er aktive under for eksempel Arktisk Råd eller internationale forskningssamarbejder. En sådan prioritering er politisk, og det er også klart, at midlerne vil skulle tages et andet sted fra, hvor de alt andet lige også gør gavn.

Det nye der dog kan komme under selvstyret, hvis Danmark indvilger i dette, vil være en grønlandsk udsendt diplomat akkrediteret til FN og/eller NATO. Det ville være nyt, og vil styrke Grønlands ekspertise og viden inden for disse organisationers aktivitetsområder.

Det er svært at se, at Grønland vil kunne opnå selvstændigt medlemskab af f.eks. NEAFC, NAFO ${ }^{34}$ og IWC, så længe, at Grønland befinder sig i nugældende statslige konstruktion med Danmark, med mindre Danmark opgiver sit eget formelle medlemskab i de to førstnævnte fora, og andre stater godkender Grønlands medlemskab.

Forbundsstats-konstruktionen er dog ikke svaret, men snarere en blindgyde. Konstruktionen kan måske give mere kompetence internt i forbundsstaten på forskellige ansvarsområder mellem de nye "delstater", men grundlæggende vil det på det formelle udenrigspolitiske område ikke give Grønland mere, da der ikke er forskellige regler for enhedsstater og forbundsstater på den internationale scene. Forbundsstats-konstruktionen vil være mere af samme vej som "integrations-modellen", hvis man eventuelt vil forsøge at placere muligheden under FN's afkoloniserings-valgmuligheder.

Free Association er den anden konstruktion, der kendes fra disse tre afkoloniseringsmuligheder. Grønland kan nemlig herigennem opnå fuldt medlemskab af FN, ligesom i andre Free Association-tilfælde. Det kan ligeledes føre til medlemskab i eget navn af Arktisk Råd, osv. Grønland vil uden tvivl kunne blive medlem af fiskeriorganisationerne NEAFC og NAFO i eget navn, og stemme uden begrænsninger i henhold til egne 
interesser. Ved medlemskabet af FN vil Grønland efterfølgende kunne blive medlem af IOC, og grønlandske idrætsfolk vil kunne deltage under eget flag ved De Olympiske Lege. Medlemskab af IWC vil også være muligt.

Medlemskab af NATO er mere uklart, da det kommer an på, hvorledes Free Associationforholdet indrettes mellem Danmark og Grønland. Det vil dog højst sandsynligt betyde, at uanset om Grønland vil få eget medlemskab af NATO eller ej, vil Grønland søge at have repræsentanter til stede i NATO-hovedkvarteret for at styrke sin ekspertise og viden inden for det sikkerhedspolitiske område. Der kan argumenteres for, at dette allerede bør være tilfældet i dag.

Grønland vil i Free Association kunne indgå folkeretlige aftaler med andre lande i eget navn - under sagsområder, som Grønland selv varetager. Samtidig vil Grønland med Free Association holde sig inden for den politiske udvikling og diskurs, som gælder for tidligere kolonier. Der er præcedens og klare udviklingsfortilfælde på dette område, og Grønland har klart muligheden for at udvikle sig længere ad denne vej. Hvis man derimod bevæger sig over i andre diskurser og politiske udviklinger - som bl.a. forbundsstats-konstruktionen kan ses som et udtryk for, - så risikerer man at miste, hvad man har opnået under FN-koloni-diskursen. Her tænker jeg blandt andet anerkendelse som folk med ret til selvbestemmelse $\mathrm{i}$ henhold til folkeretten og grundlæggende retten til selvstændighed - hvormed man ikke opnår flere betydningsfulde kompetencer på den internationale scene. Det er ikke anbefalelsesværdigt.

Jeg har et par gange hørt følgende spørgsmål stillet af danske kontakter: Hvorfor skulle Danmark indvilge i en Free Association-ordning med Grønland? Hvad får Danmark ud af det? (I spørgsmålet ligger implicit, at Danmark vil miste noget ved Free Association-ordningen med Grønland i forhold til nuværende situation. Her vil det fra et grønlandsk perspektiv være interessant at få en dansk uddybning på, hvad dette skulle være? - men lad nu dette ligge i nærværende sammenhæng).

Helt grundlæggende kan spørgsmålet besvares med følgende: Danmark har åbnet op for Free Association-vejen via selvstyreloven. Selvstyreloven, som Danmark og Grønland gennem en omfattende demokratisk proces og årelangt samarbejde er blevet enige om og yderligere har forseglet ved, at dronningen rejste til Grønland og på ceremoniel vis afleverede selvstyreloven til Grønlands Formand for Inatsisartut. Det betyder faktisk noget og forpligter. At holde Free Association-muligheden åben vil rent faktisk være det anstændige at gøre. Grønland har været en koloni i henhold til FN-kriterierne og FNPagten. Danmark har været med til at godkende og vedtage disse, og har forpligtelser som følge af dette. Man kan stille det parallelle retoriske spørgsmål: Hvorfor skulle Danmark indvilge i at respektere menneskerettighederne - hvad får Danmark ud af det? Man får forhåbentligt bedre forhold mellem folk, mindre ulighed, mere respekt og bedre samarbejde, osv. Det skulle gerne have værdi i sig selv.

I nærværende artikel, har jeg som sådan ikke diskuteret fuld selvstændighed for Grønland. Ikke fordi det vil være uinteressant, men fordi Free Association langt hen ad vejen kan udformes således, at det rent faktisk er endda meget tæt på status som fuld selvstændig stat, men med et stabiliserende samarbejde med en anden stat med større 
kapacitet. Fuld selvstændighed vil i princippet åbne op for stien henimod medlemskab af FN, Arktisk Råd, fiskeriorganisationerne, IOC, NATO og alle de andre tidligere nævnte organisationer. Med dette signaleres også et ønske om at føre og lede sit land og folk efter folkerettens bestemmelser, idet organisationerne i høj grad er fora for disse bestemmelser. Med fuld selvstændighed vil der dog også være større stabilitets- og kapacitetsmæssige spørgsmål at adressere for Grønland. Men det er dog ikke sådan, at en selvstændig stat ikke også vil kunne indgå i et styrkende samarbejde med andre stater på forskellige områder som ved Free Association-ordningerne, men man vil dog ikke længere have FN's rammer for afkolonisering at tage udgangspunkt $\mathrm{i}^{35}$

En ny statslig konstruktion er nødt til at skulle være et middel til de rammer for samfundet, som det grønlandske folk ønsker, samt et middel til at opnå de aspirationer og behov, som folket har. Konstruktionen skal lægge det juridiske fundament, rettigheder og kompetencer til at gøre de ting, som folket ønsker, og samtidig opretholde et sikkert og stabilt samfund, hvor borgerne har mulighed for at føre de liv, de ønsker inden for retsstatens rammer. Det skal meget gerne være tilfældet for den udviklingsvej, der vælges i fremtiden.

\footnotetext{
${ }^{1}$ Jeg er i skrivende stund diplomat udsendt af Grønlands Selvstyre. Denne artikel skal dog ikke læses som et udtryk for Naalakkersuisuts politik eller for Departement for Udenrigsanliggenders opfattelse, men derimod en faglig tekst, hvor vurderinger og synspunkter, der udtrykkes, er helt mine egne eller inspireret af andre. Jeg alene er ansvarlig for de synspunkter, der udtrykkes i artiklen. Jeg er cand.mag. i filosofi fra Aarhus Universitet, og er ikke jurist. Baggrunden for, at jeg alligevel vover at skrive om juridiske forhold, er blandt andet mine praktiske erfaringer med disse, herunder i Den Grønlandsk-danske Selvstyrekommission og i udenrigstjenesten.

${ }^{2}$ Kongeriget Danmark er fællesbetegnelsen for Danmark, Færøerne og Grønland i international sammenhæng. I nogle sammenhænge forkortes de tre lande med DFG.

${ }^{3}$ Danmark definerer sig selv som en enhedsstat - ikke flere stater i en. Grønland og Færøerne er ikke nødvendigvis enige i denne definition, og peger ofte på de forskellige relationer til EU, som bevis for det modsatte.

${ }^{4}$ En statslig samarbejdskonstruktion mellem to stater, hvor en stat associeres til en anden for at få assistance med at håndtere diverse statslige opgaver over en længere aftaleperiode. Konstruktionen er skabt og kendt under FN's afkoloniseringsproces - se også længere nede i artiklen.

${ }^{5}$ Grundlæggende kan siges, at det, som det grønlandske folk ønsker, bliver udtrykt gennem valg til Inatsisartut og det, som partier og politikere, der samler et flertal, giver udtryk for. Derudover kan nævnes folkeafstemningsresultatet til indførelsen af selvstyre, der gav et klart "ja" til selvstyreordningen og tilhørende udviklingsmuligheder.

${ }^{6}$ Bestemmelserne i Grundloven og selvstyreloven er længere tekstafsnit, hvorfor de ikke vil blive tilføjet her, men kan af læseren hurtigt findes på f.eks. internettet.

${ }^{7}$ Et eksempel er, at Grønland gennem tiden under mange af Arktisk Råds ministermøder har ledt Kongeriget Danmarks delegation og underskrevet på vegne af riget, hvilket også har været passende som den arktiske del af riget. Derfor er dette også muligt den dag i dag, selvom der er kommet mere fokus på Arktisk Råds aktiviteter. Kongeriget bestemmer selv, af hvem det skal lade sig repræsentere.

"'Naalakkersuisut" betyder regering på grønlandsk, og er betegnelsen for Grønlands regering. Den grønlandske betegnelse gælder ligeledes på dansk, idet Naalakkersuisut også benyttes i den danske version af selvstyreloven. Det tidligere benyttede betegnelse, "Landsstyre", var betegnelsen under hjemmestyret, og benyttes ikke i selvstyreloven. Benyttelsen af "Naalakkersuisut" på dansk signalerer respekt for det grønlandske sprog, og benyttelsen af "Landsstyre" er nu grundlæggende forældet.

9 "Fælles principerklæring mellem Regeringen og Grønlands Landsstyre om Grønlands inddragelse i udenrigs- og sikkerhedspolitikken" af 14. Maj 2003 - også kaldet Itilleq-erklæringen, navngivet efter hvor den blev underskrevet.

${ }^{10}$ Præambel i Lov om Grønlands Selvstyre.
} 
${ }^{11}$ Hvert år fremlægger Naalakkersuisut sine internationale og udenrigspolitiske aktiviteter gennem Udenrigspolitisk Redegørelse i Inatsisartut.

${ }^{12}$ Der er desværre ikke plads i denne artikel til at dykke ned i detaljerne omkring hvert forhold til de lande og multinationale organisationer, som repræsentationerne varetager.

${ }^{13}$ For mere om dette bredere sikkerhedsperspektiv, se da:

Jacobsen, M. \& Herrmann, V. (2017). Introduction: Arctic International Relations in a Widened Security

Perspective, Politik, bind 20, nr. 3, 1, s. 6-14. DOI: https://doi.org/10.7146/politik.v20i3.97174

${ }^{14}$ North-East Atlantic Fisheries Commission.

${ }^{15}$ International Olympic Committee, IOC, sættes i parentes, idet det ikke er regeringer, der repræsenterer landene, men de nationale olympiske organisationer. Dog skal nye IOC-medlemskaber efter 1996 følge anerkendelsen af FN, som stat.

${ }^{16}$ Jf. Wienerkonventionen om diplomatiske forbindelser af 1961.

17 "Ikke-selvstyrende territorier" var en anden og måske mere "politisk korrekt" betegnelse for kolonierne.

${ }^{18}$ De Forenede Nationers Pagt og Statut for den mellemfolkelige domstol; Kapitel XI - "Erklæring angående ikke-selvstyrende områder”.

${ }^{19}$ Det skete under FN's 4. Udvalg, hvor afkoloniseringsindsatsen blev håndteret. Art. 73 Kap. XI i FNPagten sætter rammerne for ånden og ved indsatsen, samt FN Faktorlisterne af 1952 og 1953. Faktorlisterne identificerede kolonierne ved "faktorer", og opridsede de politiske udviklingsmuligheder.

${ }^{20}$ UN General Assembly Resolution 1514 (XV) Declaration of the Granting of Independence to Colonial Countries and Peoples.

${ }^{21}$ UN General Assembly Resolution 1541 (XV) Defining the three options for self-determination.

${ }^{22}$ Forud for Resolution 1514 og 1541, arbejdedes der under FN med Faktorlisterne af 1952/53, hvor faktorer der kan pege i retning af Free Association omtales.

23 "Beretning til Folketinget - De Forenede Nationers femtende plenarforsamling", New York, 20. sept. 20.dec. 1960

${ }^{24}$ Se en nærmere detaljeret juridisk gennemgang af denne problematik i Gudmundur Alfredsson: "Greenland under Chapter XI of the United Nations Charter. A Continuing International Law Dispute." i" The Right to National Self-Determination - The Faroe Islands and Greenland" af Sjurdur Skaale (ed), Martinus Nijhoff Publishers, Leiden, NL, 2004.

${ }^{25}$ The United Nations and Decolonization Trust and Non-Self-Governing Territories (1945-999). Tilgængelig på: http://www.un.org/en/decolonization/nonselfgov.shtml [Tilgået d. 19. april 2019].

${ }^{26}$ Lovbemærkninger til Lov om Grønlands Selvstyre af 2009, afsnit "10.1. Adgangen til selvstændighed". Samt "Grønlandsk-dansk Selvstyrekommissions betænkning om selvstyre i Grønland" fra april 2008, kap. 3, afsnit 2.3.4. "Free Association", s. 30-31.

${ }^{27}$ Marshall Islands og Mikronesien blev efter en proces i 1990/1991 fuldgyldige medlemmer af FN som stater efter, at de havde indgået Free association-traktater med USA i henholdsvis 1983/1986 og 1986. Palau blev fuldgyldigt medlem af FN i 1994.

${ }^{28}$ Mikronesiens "COMPACT OF FREE ASSOCIATION Agreement between the UNITED STATES OF AMERICA and MICRONESIA" er fra 2003 (trådte i kraft i den 25. juni 2004), og er en opdatering af aftalen fra 1982. Marshall Islands "COMPACT OF FREE ASSOCIATION Agreement between the UNITED STATES OF AMERICA and the MARSHALL ISLANDS" er fra 2003 (ikrafttrædelse 1. maj 2004) og er en opdatering af aftalen fra 1983. Palau's "COMPACT OF FREE ASSOCIATION- between the United States and the Government of Palau" blev gældende i 1994, og den skal som udgangspunkt gælde i 50 år. ${ }^{29}$ Indgåelsen af Free Association-ordningen mellem New Zealand og Cook Islands blev godkendt ved FN's Generalforsamlings resolution 2064 af 1965. Danmark stemte i øvrigt for, og udtalte kort, at behandlingen af Cook Islands kunne tjene som eksempel for andre administrerende magter (Beretning til Folketinget - De Forenede Nationers tyvende Generalforsamling" pp. 100, New York, 21. sept.-21.dec. 1965).

30 "Joint Centenary Declaration of the Principles of the Relationship Between the Cook Islands and New Zealand", af den 11. Juni 2001.

${ }^{31}$ United Nations Framework Convention on Climate Change.

${ }^{32}$ International Whaling Commission.

${ }^{33}$ Micronesien's repræsentationer med udsendinge: Otte ambassader og repræsentationer med udsendinge (www.fsmgov.org). Palau's repræsentationer med udsendinge: Syv ambassader og repræsentationer (www.palaugov.pw). Marshall Islands repræsentationer med udsendinge: Syv ambassader og repræsentationer (www.embassypages.com). Ambassaderne og repræsentationerne er også forholdsvist små, og er i deres bemanding i størrelsesorden sammenlignelige med Grønlands repræsentationer i dag. 


\footnotetext{
${ }^{34}$ North Atlantic Fisheries Organization.

${ }^{35}$ Førnævnte FN-pagten, diverse FN-resolutioner og deklarationer, eksempler for andre anerkendte/godkendte afkoloniseringsforhold, osv.
} 